\title{
KOMPONEN BIOAKTIF DAN AKTIVITAS ANTIOKSIDAN EKSTRAK KASAR Sargassum plagyophyllum
}

\author{
Edison, Andarini Diharmi*, Nurul Muji Ariani, Mirna Ilza \\ Jurusan Teknologi Hasil Perikanan,Fakultas Perikanan dan Kelautan, Universitas Riau, Kampus Bina \\ Widya, Jalan HS Soebrantas km 12,5 Simpang Baru, Panam, Pekanbaru 28293
}

*Korespondensi: rini_abrar@yahoo.com

Diterima: 4 November 2019/Disetujui: 30 April 2020

Cara sitasi: Diharmi A, Edison, Ariani NM, Sumarto, Mirna Ilza. 2020. Komponen bioaktif dan aktivitas antioksidan ekstrak kasar Sargassum plagyophyllum. Jurnal Pengolahan Hasil Perikanan Indonesia. 23(1): 58-66.

\begin{abstract}
Abstrak
Rumput laut cokelat (Sargassum plagyophyllum) berpotensi sebagai antioksidan alami karena memiliki kandungan flavonoid dan fenolik. Penelitian ini bertujuan untuk menentukan komposisi proksimat, mengidentifikasi komponen bioaktif, dan aktivitas antioksidan ekstrak kasar S.plagyophyllum. Penelitian ini menggunakan metode eksperimen dengan melakukan ekstraksi S. plagyophyllum menggunakan beberapa pelarut organik, antara lain: n-heksana, etil asetat, dan metanol. Parameter analisis terdiri atas analisis proksimat, rendemen, fitokimia, dan aktivitas antioksidan menggunakan metode DPPH. Hasil penelitian menunjukkan komposisi kimia (kadar air, abu, protein, lemak, karbohidrat, dan total serat kasar) berturut-turut sebesar 15,98 (bb); $21,38 \%$; protein 9,05\%; 0,88\%; 68,69\%; $22,24 \%$ (bk). Rendemen ekstrak heksana, etil asetat, dan metanol adalah 0,6; 0,28; dan 0,31\%. Hasil ekstraksi dengan pelarut heksana didapatkan senyawa steroid/triterpenoid; pelarut etil asetat didapatkan senyawa alkaloid, flavonoid, steroid/ triterpenoid, saponin, dan fenolik; sedangkan ekstraksi dengan pelarut metanol didapatkan semua komponen bioaktif kecuali flavonoid. Aktivitas antioksidan ekstrak Sargassum plagyophylum dengan heksana, etil asetat, dan metanol dihasilkan nilai nilai $\mathrm{IC}_{50}$ 1105,58 ppm; 532,42 ppm; dan 777,79 ppm.
\end{abstract}

Kata kunci: DPPH, ekstraksi, pelarut organik, rumput laut cokelat.

\section{Bioactive Components and Antioxidant Activity of Sargassum plagiophyllum Crude Extract}

\begin{abstract}
Brown seaweed (Sargassum plagyophyllum) is known to contain natural antioxidants, namely flavonoids and phenolics. This study was aimed to determine the proximate composition of S. plagyophyllum, identify bioactive components, and antioxidant activity of the crude extracts of S. plagiophyllum. Bioactive components were extracted using several organic compounds including $\mathrm{n}$-hexane, ethyl acetate, and methanol. The analysis parameters consisted of proximate analysis, yield, phytochemical, and antioxidant activity using the DPPH method. The results showed that the chemical composition of $S$. plagyophyllum seaweed were moisture 15.98 (ww), ash $21.38 \%$, lipid $0.88 \%$, protein $9.05 \%$, carbohydrates $68.69 \%$ and crude fiber $22.24 \%(\mathrm{dw})$. The yield of extract with hexane, ethyl acetate, and methanol were $0.6,0.28$, and $0.31 \%$, respectively. The hexane extract contained steroid/triterpenoid compounds while ethyl acetate extract contained alkaloids, flavonoids, steroids/ triterpenoids, saponins, and phenolics. The methanolic extract contained all bioactive components except flavonoids. Hexane, ethyl acetate and methanolic extract had antioxidant activity with $\mathrm{IC}_{50}$ values $1105.58 \mathrm{ppm}, 532.42 \mathrm{ppm}$, and $777.79 \mathrm{ppm}$, respectively.
\end{abstract}

Keywords: brown seaweed, DPPH, extraction, organic solvent

\section{PENDAHULUAN}

Komoditas unggulan perikanan salah satunya adalah rumput laut yang tersebar di perairan Indonesia sebagai komoditi ekspor potensial untuk dikembangkan. Produksi rumput laut dari tahun 2013-2016 mengalami peningkatan dari 21,99- 27,19\% (KKP 2017). Salah satu jenis rumput laut yang potensial berasal dari kelas alga cokelat adalah S. plagyophyllum.

Rumput laut cokelat teridentifikasi mengandung pigmen (fukosantin, astasantin, karotenoid) dan polifenol (asam fenolik, flavonoid, tanin) yang berfungsi sebagai antioksidan, antimutagenik, anti koagulan, anti tumor dan metabolisme lipid. Kandungan rumput laut cokelat berupa metabolit sekunder 
berupa senyawa aktif terdiri atas alkaloid, glikosida, tanin dan steroid bermanfaat untuk pengobatan dan industri farmasi (Jeeva et al. 2012). laut cokelat yang berpotensi sebagai antioksidan alami (Nurjanah et al. 2019; Dolorosa et al. 2019; Hidayat et al. 2018; Dolorosa et al. 2017; Hidayat et al. 2017; Nurjanah et al. 2017; Yanuarti et al. 2017; Maharani et al. 2017; Lutfiyana et al. 2016; Nurjanah et al. 2016; Ganapathi et al. 2013); Firdaus et al. (2012); dan Foon et al. (2013).

Metabolit sekunder dari rumput laut didapatkan dengan cara ekstraksi. Salah satu metode ekstraksi dengan cara merendam (maserasi) sampel dengan pelarut organik misalnya heksana, etil asetat, etanol, dan metanol. Gritter et al. (1991) menyatakan bahwa senyawa non polar larut pada non polar seperti eter, kloroform, dan n-heksan. Pelarut heksana, etil asetat, dan metanol berfungsi menarik senyawa aktif berdasarkan polaritas dari non polar, semi polar, hingga polar untuk mengektraks suatu komponen sehingga menghasilkan senyawa yang dikehendaki. Menurut Harbone (1987) keberhasilan dalam proses ekstraksi ditentukan oleh jenis dan mutu pelarut yang digunakan.

Heksana merupakan pelarut organik bersifat non polar yang berfungsi melarutkan lilin, lemak, dan minyak dari bahan. Pemilihan heksan dalam proses ekstraksi sebagai pelarut pertama supaya komponen lemak pada bahan dapat terpisahkan terlebih dahulu, bertujuan untuk tidak menghalangi keluarnya bahan aktif pada proses ekstraksi dengan pelarutpelarut lainnya. Pelarut heksana berfungsi untk mengeluarkan senyawa aktif steroid/ terpenoid. Pelarut etil asetat dapat menarik komponen seperti fenol, terpenoid, dan alkaloid, sedangkan pelarut metanol dapat menarik komponen seperti alkaloid, fenolik, karotenoid (Harborne 1987).

Komponen bioaktif yang terdapat dari tanaman ataupun hewani seperti fenolik dan flavonoid merupakan sumber antioksidan yang potensial. Antioksidan merupakan suatu inhibitor yang berfungsi untuk mencegah autooksidasi. Antioksidan alami mengandung berbagai senyawa, misalnya fenolat (fenol dan polifenol), flavonoid, karotenoid, steroid dan senyawa tiol ( $\mathrm{Lu}$ et al. 2010)
Sargassum plagyophyllum sebagai salah satu rumput laut cokelat yang potensial untuk antioksidan, tetapi informasinya masih minim. Oleh karena itu, perlu dilakukan penelitian untuk mendapatkan aktivitas antioksidan dari S. plagyophyllum dengan ekstraksi maserasi bertingkat. Penelitian ini bertujuan untuk menentukan komponen bioaktif dan aktivitas antioksidan ekstrak S. plagyophyllum.

\section{BAHAN DAN METODE Bahan dan Alat}

Bahan yang digunakan dalam penelitian ini adalah rumput laut cokelat $S$. plagyophyllum yang dikeringkan petani dari hasil budidaya di Pantai Sepanjang Gunung Kidul, Yogyakarta, $\mathrm{H}_{2} \mathrm{SO}_{4}$ (Merck), $\mathrm{NaOH}$ $50 \%$ (Merck), $\mathrm{H}_{3} \mathrm{BO}_{3}$ (Merck), $\mathrm{Cu}$, indikator pp kompleks, indikator metilen merah biru, etanol 95 (Merck), n-heksana (Merck), etil asetat (Merck), metanol (Merck), serbuk $\mathrm{Mg}, \mathrm{HCl}$ pekat (merck), $\mathrm{HCl} 0,1 \mathrm{~N}$ (Merck), reagen Mayer, Dragendroff, $\mathrm{HCl} 1 \mathrm{~N}, \mathrm{H}_{2} \mathrm{SO}_{4}$ pekat (pa, Merck), metanol 50\%, kloroform (Merck), asetat anhidrat, DPPH (1,1-difenil2-pikrilhidrazil) (sigma-Aldrich), akuades, standar asam askorbat/vitamin C (SigmaAldrich), tissu, aluminium foil, kertas saring Whattman 42, dan kapas.

Alat yang digunakan antara lain: microplate reader (Berthold Tristar LB 941), rotary evaporator (BUCHI Waterbath B-480), dan ultrasonikator (Branson 1510).

\section{Metode Penelitian}

Metode penelitian yang digunakan adalah eksperimen laboratorium dengan mengekstrak senyawa bioaktif $S$. plagiophyllum dengan maserasi bertingkat. Ekstraksi dilakukan dengan menggunakan pelarut heksan, etil setat, dan metanol. Parameter analisis terdiri atas analisis proksimat bahan baku, rendemen ekstrak, komponen fitokimia (biaoktif), dan aktivitas antioksidan pada ekstrak.

\section{Preparasi bahan baku}

Rumput laut S. plagiophyllum dicuci dengan air bersih sebanyak 3 kali untuk menghilangkan kotoran yang terdapat pada rumput laut dan ditiriskan. Setelah itu rumput laut dicuci, dikeringkan dengan cara diangin- 
anginkan atau tidak langsung terkena cahaya matahari. Rumput laut setelah kering kemudian dilakukan analisis proksimat dan dihaluskan dengan ukuran partikel 60 mesh.

\section{Ekstraksi S.plagyophyllum}

Ekstraksi rumput laut S. plagyophyllum dilakukan dengan maserasi bertingkat menggunakan pelarut heksana, etil asetat, dan metanol mengacu pada Yanuarti et al. (2017). S. plagyophyllum yang telah dihaluskan sebanyak $200 \mathrm{~g}$ dimasukkan ke dalam botol kemudian dilarutkan dengan heksana 400 $\mathrm{mL}(1: 2 \mathrm{~b} / \mathrm{v})$ dan diekstraksi secara maserasi selama 72 jam (tingkat 1), kemudian disaring. Filtrat disimpan sebelum dievaporasi dan residu diektraksi kembali dengan etil asetat 1:2 (b/v) dimaserasi kembali selama 72 jam (tingkat 2). Setelah maserasi dengan etil asetat dilakukan penyaringan didapatkan filtrat dan residu. Residu dari pelarut etil asetat dimaserasi dengan metanol selama 72 jam (tingkat 3). Hasil dari maserasi masing-masing pelarut tersebut dihasilkan filtrat. Ketiga filtrat tersebut dievaporasi menggunakan rotary evaporator dengan suhu $40^{\circ} \mathrm{C}$ bertujuan untuk menguapkan pelarut. Rendemen ekstrak yang diperoleh dihitung kemudian dilakukan analisis fitokimia dan aktivitas antioksidan.

\section{Analisis rendemen (AOAC 2005)}

Rendemen ekstrak didapatkan dari hasil presentase bobot ekstrak yang dihasilkan dibagi dengan bobot sampel yang digunakan. Persamaan untuk menghitung rendemen:

Rendemen $=\frac{\text { berat ekstrak }(\mathrm{g})}{\text { berat sampel }(\mathrm{g})} \times 100 \%$

\section{Analisis alkaloid (Harborne 1996)}

Ekstrak ditimbang sebanyak $50 \mathrm{mg}$ dimasukkan ke dalam tabung reaksi dan dilarutkan di dalam $2 \mathrm{~mL}$ kloroform dan $2 \mathrm{~mL}$ ammonia setelah larut dan disaring. Filtrat hasil penyaringan ditambahkan dengan $\mathrm{H}_{2} \mathrm{SO}_{4}$ pekat sebanyak 3-5 tetes dan dikocok sampai homogen dan terbentuk dua lapisan. Selanjutkan diambil fraksi asam ditambahkan dengan reagen Mayer dan Dragendroff masingmasing sebanyak 4-5 tetes. Terbentuknya endapan menunjukkan adanya alkaloid, reagen Mayer terbentuk endapan berwarna putih dan
Dragendroff endapan berwarna merah jingga.

Analisis flavonoid (Harborne 1996)

Ekstrak sebanyak $50 \mathrm{mg}$ dilarutkan dalam $100 \mathrm{~mL}$ air, dipanaskan sampai mendidih dan disaring. Filtrat diambil sebanyak $5 \mathrm{~mL}$ dan dimasukkan ke dalam tabung reaksi dan ditambahkan 0,05 mg Mg dan $1 \mathrm{~mL} \mathrm{HCl}$ pekat dan dikocok kuat kemudian dibiarkan sampai terjadi pemisahan dan terjadi perubahan warna warna merah, kuning atau jingga.

\section{Analisis steroid dan triterpenoid (Harborne 1996)}

Ekstrak sebanyak $50 \mathrm{mg}$ diteteskan dengan $\mathrm{CH}_{3} \mathrm{COOH}$ pekat sebanyak 10 tetes dan $\mathrm{H}_{2} \mathrm{SO}_{4}$ pekat 2 tetes. Ekstrak yang sudah dicampur dengan $\mathrm{CH}_{3} \mathrm{COOH}$ pekat dan mengandung $\mathrm{H}_{2} \mathrm{SO}_{4}$ pekat diaduk perlahan dan dibiarkan beberapa menit. Uji positif ekstrak mengandung steroid jika terjadi perubahan warna menjadi warna biru atau hijau, sedangkan untuk terpenoid terbentuknya warna merah atau ungu.

\section{Analisis fenolik (Harborne 1996)}

Ekstrak sebanyak $50 \mathrm{mg}$ diteteskan dengan $\mathrm{FeCl} 31 \%$ seebanyak 10 tetes, terbentuknya warna hijau, merah, ungu, biru atau hitam pekat menunjukkan ekstrak mengandung fenolik.

\section{Analisis antioksidan (Zhang et al. 2006)}

Aktivitas antioksidan dianalisis dengan metode DPPH ((1,1-Diphenyl-2-picryl Hydrazil) secara microplate reader two old delution pada panjang gelombang $517 \mathrm{~nm}$ mengacu pada Zhang et al.(2006). Terdiri atas beberapa tahapan antara lain:

a. Melarutkan $2 \mathrm{mg}$ ekstrak di dalam 2 $\mathrm{mL}$ metanol dan konsentrasi larutan dan konsentrasi sampel ditepatkan menjadi 1000 $\mu \mathrm{g} / \mathrm{mL}$

b. Plate reader terdiri atas 8 baris diberi simbol A-H dan setiap baris terdapat 12 sumur. Sumur-sumur pada baris-A diisi sebanyak $100 \mu \mathrm{L}$ sampel. Kolom/baris (BF) setiap sumur diisi dengan metanol $50 \mu \mathrm{L}$. c. Diambil sebanyak $50 \mu \mathrm{L}$ pada baris A dan dimasukkan ke baris/kolom B, diambil pada baris B $50 \mu \mathrm{L}$ dimasukkan ke baris C. Sama halnya telah dilakukan pada baris B sampai baris F, kecuali untuk baris F diambil $50 \mu \mathrm{L}$ 
dan tidak digunakan, sehingga didapatkan konsentrasi menjadi 1000; 500; 250; 125; 62,5 ; dan $31,25 \mu \mathrm{g} / \mathrm{mL}$. Sumur-sumur di baris G-H diisi dengan $50 \mu \mathrm{L}$ metanol, untuk baris $\mathrm{H}$ diisi dengan metanol sumur 1-6. d. Sumur-sumur pada baris A-G ditambahkan dengan larutan DPPH sebanyak $80 \mu \mathrm{L}$ dengan konsentrasi $40 \mu \mathrm{g} /$ $\mathrm{mL}$ setelah selesai sebelum diukur dengan spektrofotometer didiamkan selama 30 menit kemudian dilakukan pengukuran aktivitas antioksidan. Pengukuran aktivitas antioksidan ditujukkan dengan penurunan absorbansi larutan DPPH dengan microplate reader.

Perhitungan nilai \% inhibisi menggunakan persamaan sebagai berikut:

$\%$ Hambatan (inhibisi) $=\frac{\text { (A kontrol-A sampel) }}{\text { A kontrol }} \times 100 \%$ Keterangan:

A kontrol = absorbansi tidak mengandung sampel A sampel $=$ absorbansi sampel

\section{Analisis data}

Data yang didapat dihitung berdasarkan persamaan dan dianalisis secara deskriptif secara konprehensif dengan literatur yang sesuai. Selanjutnya disajikan dalam bentuk tabel, skema dan gambar yang kemudian ditarik kesimpulan dari hasil analisis.

\section{HASIL DAN PEMBAHASAN}

\section{Komposisi Proksimat S. plagyophyllum}

Hasil analisis proksimat dan serat kasar rumput laut $S$. plagiophyllum disajikan pada Table 1.

Table 1 Chemical composition of S. plagyophyllum

\begin{tabular}{cr}
\hline Composition & \multicolumn{1}{c}{$(\% \mathrm{db})$} \\
\hline Moisture & $15.98 \pm 0.46^{\star}$ \\
Ash & $21.38 \pm 0.17$ \\
Lipid & $0.88 \pm 0.01$ \\
Protein & $9.05 \pm 0.07$ \\
Carbohydrate (by difference) & $68.69 \pm 0.93$ \\
Fiber & $22.24 \pm 0.50$ \\
\hline
\end{tabular}

Information: ${ }^{\star}$ wet basis, dw (dry weight)

Hasil analisis menunjukkan bahwa ratarata kandungan air yaitu 15,98\% (bb). Kadar rumput laut kering menurut SNI 2690.1-2009 (BSN 2006) adalah air maksimal 30 (\%bk).
Kadar air rumput laut S. plagiophyllum pada penelitian ini telah memenuhi standar SNI.

S. plagiophyllum memiliki kadar abu sebesar $21,38 \%$ (bk). Kadar abu relatif lebih rendah dari kadar abu hasil penelitian Diachanty et al. (2017) dan Matanjum et al. (2009) pada rumput laut coklat jenis Turbinaria conaides dan T. tetrasmatica dengan kadar abu 27,5827\% (bk). Handayani et al. (2004) menyatakan bahwa penyerapan mineral Sargassum sp. melalui permukaan talus, tidak melalui akar sehingga penyerapan mineral lebih efektif.

Rata-rata kadar lemak adalah 0,88\% (bk). Kadar lemak S. plagiophyllum lebih tinggi daripada $S$. polycystum yaitu 0,23$0,50 \%$ (bk) (Manteu et al. 2018; Diachanty et al. 2017). Kadar lemak S. plagiophyllum juga lebih tinggi daripada jenis $T$.conoides $(0.47 \%)$ dan S. polycystum (0,29\%) (Felix dan Brindo et al. 2014). Matanjum et al. (2009), melaporkan kadar abu untuk $T$. tetrasmatica lebih tinggi $(1,14 \%)$ daripada $S$. plagiophyllum. Kumar et al. (2011) menyatakan bahwa lemak rumput laut umumnya $<4 \%$ dan lebih rendah dari tanaman darat.

Kadar protein rumput laut relatif rendah dibandingkan dengan kadar air, abu dan karbohidrat (Table 1). Kadar protein adalah sebesar 9,05\% (bk). Protein dari S. plagiophyllum kadarnya lebih tinggi dari protein Sargassum sp. 5,53\% (bk) (Gazali et al. 2018). Protein rumput laut cokelat adalah lebih rendah (3-15\% bk), dibandingkan dengan rumput laut hijau dan merah (10-47\% bk) (Fleurence 1999). Kadar protein rumput laut S. plagyohyllum pada penelitian ini hampir sama dengan kadar protein untuk jenis S. milicifolium yaitu $9,71 \%$ (bk), (Ganapathi et al. 2013)

Rumput laut merupakan sumber karbohidrat dan serat. Parthiban et al. (2013) menyatakan bahwa rumput laut kadar karbohidratnya berkisar 10,63- 28,58\%, protein $9,47-14,68 \%$ dan lemak $0,15-0,84 \%$ Perbedaan kandungan proksimat pada rumput laut disebabkan karena adanya perbedaan perbedaan kondisi lingkungan, musim panen dan habitat rumput laut (Ahmad et al. 2012). Rata-rata kadar karbohidrat rumput laut S. plagyophyllum adalah sebesar $68,69 \%$ (bk). Karbohidrat pada rumput laut cokelat 
terdiri dari fukoidan, laminaran, selulosa dan alginat (Vijay et al. 2017). Kadar serat kasar $S$. plagyophyllum adalah 22,24\% (bk). Ate et al. (2017) menyatakan bahwa kandungan nilai serat kasar rumput laut pada umumnya yaitu $30-40 \%$ bk.

\section{Rendemen Ekstrak S. plagyophyllum}

Rendemen adalah adalah perbandingan jumlah (kuantitas) ekstrak yang dihasilkan dari ekstraksi tanaman/hewan. Nilai ratarata rendemen ekstrak S. plagyophyllum yang dihasilkan disajikan pada Table 2.

Table 2 Yield of S. plagyophyllum

\begin{tabular}{cc}
\hline Solvent & Yield (\%) \\
\hline Hexane & $0.06 \pm 0.00$ \\
Ethyl Acetate & $0.28 \pm 0.01$ \\
Methanol & $0.31 \pm 0.06$ \\
\hline
\end{tabular}

Table 2 menunjukkan rendemen ekstrak metanol paling tinggi daripada ekstrak etil asetat dan heksana. Rendemen terkecil dihasilkan dari ekstrak kasar dengan heksana karena komponen bioaktif yang terlarut dalam pelarut non polar relatif sedikit, sedangkan pada pelarut polar (metanol) yang larut dengan jumlah lebih banyak (Table 3). Hasil rendemen ekstrak kasar dihasilkan tertinggi hasil ektraksi dengan metanol, diikuti etil asetat dan paling rendah dengan heksan. Terjadinya perbedaan rendemen ini dipengaruhi oleh jenis pelarut yang digunakan. Salamah et al. (2008) menjelaskan bahwa rendemen ekstrakyang dihasilkan dipengaruhi beberapa faktor, di antaranya metode ekstraksi, ukuran partikel sampel, kondisi, waktu penyimpanan, lama waktu ekstraksi, perbandingan jumlah sampel dengan pelarut, dan jenis pelarut yang digunakan.

Metanol merupakan bentuk alkohol dengan rumus kimianya $\mathrm{CH}_{3} \mathrm{OH}$. Sruktur kimia metanol terdiri atas gugus hidroksil (polar) dan gugus karbon (non polar) sehingga metanol bersifat polar. Ekstraksi dengan metanol menghasilkan ektrak yang lebih banyak, karena sifat metanol yang sangat polar diduga dapat mengekstrak komponen bioaktif lebih banyak yang bersifat sangat polar dan sedikit non polar yang terdapat dalam S. plagyophyllum (Supriyanti 2010).

\section{Komponen Bioaktif}

Table 3 menunjukkan bahwa kandungan senyawa bioaktif yang dihasilkan berbeda untuk jenis pelarut yang digunakan. Secara umum, senyawa bioaktif S. plagyophyllum paling banyak terdapat pada ekstrak dengan pelarut etil asetat. Hal ini menyatakan bahwa senyawa fitokimia dalam S. plagyophyllum cenderung larut dalam pelarut semi polar. Senyawa aktif $S$. plagiophyllum ekstrak heksana dihasilkan steroid/triterpenoid, ekstrak etil asetat yaitu alkaloid, flavonoid, steroid/triterpenoid, saponin, dan fenolik, sedangkan ekstrak metanol tidak terdapat senyawa flavonoid.

Alkaloid merupakan metabolit sekunder dari tanaman. Alkaloid terdiri atas tiga bagian elemen yang mengandung nitrogen berfungsi untuk pembentukan alkaloid dan reaksi yang terjadi untuk pengikatan khas elemen-elemen pada alkaloid (Sirait 2007). Analisis fitokimia untuk menentukan alkaloid terhadap ekstrak S. plagyophyllum tidak terdapat endapan pada pelarut heksana setelah direaksikan dengan pereaksi Meyer dan Dragendroff. Alkaloid bersifat tidak larut dalam heksana, larut dalam etil asetat (semi polar), dan metanol (polar) (Harborne 1987). Struktur kimia alkaloid adalah atom nitrogen pada bagian sikliknya dan berikatan dengan gugus amina, amida, fenol dan metoksi sehingga alkaloid bersifat semi polar (Purba 2001). Senyawa alkaloid bersifat semi polar sehingga lebih larut dalam pelarut semi polar.

Ekstrak S. plagyophyllum dengan etil asetat dihasilkan flavonoid. Senyawa flavonoid bersifat non polar, karena struktur kimia flavonoid memiliki gugus gula sehingga mudah larut dalam polar ataupun semi polar. Komponen bioaktif flavonoid banyak ditemukan pada batang tumbuhan (Kar et al. 2016).

Hasil analisis esktrak untuk menentukan komponen bioaktif steroid dan terpenoid menunjukkan terjadinya perubahan menjadi biru kehijauan. Komponen bioaktif jenis steroid dan terpenoid dihasilkan dari ekstrak S. plagyophyllum didapatkan dengan menggunakan pelarut heksana, etil asetat, dan metanol. Keberadaan steroid pada ketiga pelarut ini karena ketiga jenis pelarut 
Table 3 Bioactive component of S. plagyophyllum extracts

\begin{tabular}{|c|c|c|c|c|c|}
\hline \multirow{2}{*}{ Component } & \multicolumn{3}{|c|}{ Solvent } & \multirow{2}{*}{ Reagent } & \multirow[t]{2}{*}{ Color Standard } \\
\hline & Hexana & Ethil Acetate & Methanol & & \\
\hline Alkaloid & - & + & ++ & Meyer, Dragendroff & $\begin{array}{c}\text { white precipitate, red } \\
\text { precipitate }\end{array}$ \\
\hline Flavonoid & - & ++ & - & Sianidin test & red solution \\
\hline $\begin{array}{l}\text { Steroid/ } \\
\text { Triterpenoid }\end{array}$ & ++++ & +++ & + & Liberman- Burchard & greenish blue \\
\hline Saponin & - & + & ++++ & $\mathrm{H}_{2} \mathrm{O}$ & foam formed \\
\hline Phenolic & - & +++ & + & $\mathrm{FeCl}_{3} 1 \%$ & blue/purple solution \\
\hline
\end{tabular}

memiliki momen dipol senyawa polar dan semi polar sehingga menginduksi molekul non polar yang tidak memiliki dipol dan terjadi gaya elektrostatik di antara keduanya. Menurut Rosyidah et al. (2010) steroid/ triterpenoid memiliki fungsi untuk menghambat pertumbuhan bakteri.

Hasilidentifikasi komponenbioaktif(Tabel 3), ekstrak S. plagyophyllum menggunakan etil asetat dan metanol adanya senyawa saponin dan ekstrak dengan heksana tidak terdeteksi. Perbedaan kepolaran pelarut merupakan salah satu faktor yang menyebabkan tidak terdeteksinya saponin pada ekstrak dengan pelarut non polar seperti heksana.

Analisis ekstrak menggunakan etil asetat dan metanol menunjukkan adanya senyawa fenolik, sebaliknya dengan heksana tidak terdapat senyawa fenolik. Senyawa fenolik tidak terekstrak oleh pelarut heksana yang bersifat non polar. Septiana et al. (2002) senyawa fenolik umumnya lebih mudah diekstrak dengan senyawa pelarut organik semi polar dan polar.

\section{Aktivitas Antioksidan Ekstrak S. plagyophyllum}

Pengujian aktivitas antioksidan ekstrak menggunakan metode DPPH (1,1-difenil2-pikrilhidrazil) dengan microplate reader twofold delution dengan konsentrasi larutan berturut-turut dari 1000; 500; 250; 125; 62,5; dan $31,25 \mu \mathrm{g} / \mathrm{mL}$. Metode DPPH digunakan untuk menguji aktivitas antioksidan karena sederhana, mudah, waktu pengujian singkat, sampel yang digunakan tidak terlalu banyak, dan tidak memerlukan banyak reagen (Juniarti et al. 2009).
Aktivitas antioksidan menggunakan metode DPPH diinterpretasikan menggunakan nilai $\mathrm{IC}_{50}$. Nilai IC $\mathrm{IC}_{50}$ (Inhibition Concentration) adalah konsentrasi ekstrak yang dapat menyebabkan berkurangnya 50\% aktivitas DPPH (Molyneux 2004). Hasil analisis pengujian aktivitas antioksidan ekstrak S. plagiophyllum disajikan pada Table 4.

Table $4 \mathrm{IC}_{50}$ S. plagyophyllum extract

\begin{tabular}{cc}
\hline Solvent & $\mathrm{IC}_{50}(\mathrm{ppm})$ \\
\hline Hexane & $1105.58 \pm 16.62$ \\
Ethyl Acetate & $532.42 \pm 7.80$ \\
Methanol & $777.79 \pm 16.82$ \\
\hline
\end{tabular}

Aktivitas antioksidan ketiga ekstrak dengan pelarut yang berbeda menunjukkan dari nilai $\mathrm{IC}_{50}$ pelarut etil asetat memiliki aktivitas antioksidan yang tinggi. Aktivitas antioksidan ekstrak etil asetat lebih tinggi dibandingkan heksana dan metanol, hal ini berkaitan dengan kandungan senyawa aktif yang dihasilkan dari ekstrak etil asetat yaitu adanya fenolik dan flavonoid (Table 3). Komponen fenolik dan flavonoid merupakan komponen bioaktif yang berperan sebagai antioksidan. Yudiati et al. (2011) menyatakan nilai $\mathrm{IC}_{50}$ kecil menunjukkan aktivitas antioksidannya semakin kuat dan begitu juga sebaliknya. Aktivitas antioksidan sangat kuat, kuat, lemah, dan sangat lemah berturut-turut dengan nilai $\mathrm{IC}_{50}<500 \mathrm{ppm}, \mathrm{IC}_{50} 50-100 \mathrm{ppm}$, $\mathrm{IC}_{50} 101-250 \mathrm{ppm}, \mathrm{IC}_{50} 251-500 \mathrm{ppm}$ dan $\mathrm{IC}_{50}$ $>500$ ppm (Molyneux 2004). Hasil analisis aktivitas antioksidan ekstrak S. plagyophyllum tergolong sangat lemah karena memiliki nilai $\mathrm{IC}_{50}>500 \mathrm{ppm}$. Hasil penelitian ini sesuai 
dengan penelitian Renhoran (2012) terhadap ekstrak Sargassum polycystum dengan heksana dihasilkan aktivitas antioksidan pada rumput dengan nilai $\mathrm{IC}_{50}$ yaitu 1174,98 ppm.

Ketiga ekstrak tersebut tergolong sangat lemah, karena hal ini diduga karena sampel yang diuji berupa ekstrak kasar. Menurut Husni et al. (2014), kerja antioksidan ekstrak kasar diduga dihambat karena masih terdapatnya senyawa-senyawa lain seperti garam, mineral, dan nutrien-nutrien. Aktivitas antioksidan suatu bahan juga dipengaruhi oleh tipe pelarut, metode ekstraksi, musim, lokasi, dan jenis spesies (Budhiyanti et al. 2012).

\section{KESIMPULAN}

Komponen bioaktif S. plagyophyllum ekstrak dengan etil asetat ditemukan semua komponen bioaktif yaitu flavonoid, steroid/ triterpenoid, saponin, alkaloid, dan fenolik. Aktivitas antioksidan ekstrak S. plagyophyllum terbaik yaitu dengan pelarut etil asetat.

\section{UCAPAN TERIMA KASIH}

Penelitian ini sebagian telah didanai PNPB Universitas Riau Tahun Anggaran 2019 melalui Lembaga Penelitian dan Pengabdian Kepada Masyarakat pada Skim Penelitian Bidang Ilmu Tahun 2019.

\section{DAFTAR PUSTAKA}

Ahmad F, Sulaiman MR, Saimon W, Yee CF, Matanjun P.2012.Proximate compositions and total phenolic contents of selected edible seaweed from Semporna, Sabah, Malaysia. Borneo Science. (31): 85-96.

[AOAC] The Association of Official Analytical Chemists. 2005. Official Methods of the Analysis of the Association of Official Analytical of Chemist. Virgina (US): The Association of Analytical Chemist, Inc.

[BSN] Badan Standardisasi Nasional. 2006. Cara uji kimia bagian 2: penentuan kadar air pada produk perikanan. SNI 01-2354.2-2006. Jakarta (ID): Badan Standardisasi Nasional.

[KKP] Kementerian Kelautan dan Perikanan. 2017. KKP sasar rumput laut sebagai komoditas unggulan budidaya. http:// www.kkp.go.id.

Astawan M dan Kasih AL. 2008. Khasiat
Warna-warni Makanan. Jakarta (ID). Gramedia Pustaka Utama.

Ate JNB, Junet F dan Theresia PES. 2017. Analisis kandungan nutrisi Gracilaria edule (S.G. GMELIN) P.C. Silva dan Gracilaria coronopifolia J. Agardh. untuk pengembangan perekonomian masyarakat pesisir. Jurnal Ilmu Kesehatan. 5(2): 94-103.

Budhiyanti SA, Sri R, Djagal WM, Iwan YBL. 2012. Antioxidant activity of brown algae Sargassum species extract from the coastline of Java Island. American Journal of Agricultural and Biological Sciences. 7(3): 337-346.

Diachanty S, Nurjanah, Abdullah A. 2017. Aktivitas antioksidan berbagai jenis rumput laut cokelat dari Perairan Kepulauan Seribu. Jurnal Pengolahan Hasil Perikanan Indonesia. 20(2): 305318.

Dolorosa MT, Nurjanah, Purwaningsih S, Anwar E, Hidayat T. 2019 Tyrosinase inhibitory activity of Sargassum plagyophyllum and Eucheuma cottonii methanol extracts. IOP Conference Series: Earth and Environmental Science. 278 (1): 1715-1375..

Dolorosa MT, Nurjanah, Purwaningsih S, Anwar E, Hidayat T. 2017. Kandungan senyawa bioaktif bubur rumput laut Sargassum plagyophyllum dan Eucheuma cottonii sebagai bahan baku krim pencerah kulit. Jurnal Pengolahan Hasil Perikanan Indonesia. 20(3): 633-644.

Felix N, Brindo A. 2014. Effects of raw and fermented seaweed, Padina tetrastomatica on the growth and food conversion of giant freshwater prawn Macrobrachium rosenbergii. International Journal of Fisheries and Aquatic Studies. 1(4): 108113.

Firdaus M, Astawan M, Muchtadi D, Wresdiyati T, Waspadji S, Karyono SS. 2012. Toksisitas akut ekstrak metanol rumput laut cokelat Sargassum echinocarpum. Jurnal Pengolahan Hasil Perikanan Indonesia. 15(2): 148-155

Fleurence J. 1999. Seaweed proteins: biochemical, nutritional aspects and potential uses. Trends in Food Science and 
Technology. 10(1)25-28.

Foon TS, Ai LA, Kuppusamy P, Yusoff MM, Govindan N. 2013. Studies on in-vitro antioxidant activity of marine edible seaweeds from the east coastal region of peninsular malaysia using different extract methods. Journal of Coastal Life Medicine. 1(3): 193-198.

Ganapathi K, Subramanian V, Mathan S. 2013. Bioactive potentials of brown seaweeds, Sargassum myriocystum, S.plagiophyllum and S. ilicifolium (Turner) J. Agardh. International Research Journal of Pharmaceutical and Applied Sciences. 3(5): 105-111.

Gazali M, Nurjanah dan Neviaty PZ. 2018. Eksplorasi senyawa bioaktif alga cokelat Sargassum sp. Agardh sebagai antioksidan dari pesisir barat Aceh. Jurnal Pengolahan Hasil Perikanan Indonesia. 21(1): 167178.

Gritter RJ, Robbat JM, Schwarting Ae. 1992. Pengantar Kromatografi. Bandung (ID): ITB Press.

Handayani T, Sutarno, Ahmad DS. 2004. Analisis komposisi nutrisi rumput laut Sargassum crassifolium J. Agardh. Biofarmasi. 2(2): 45-52.

Harborne JB. 1987. Metode Fitokimia: Penuntun Cara Modern Menganalisis Tumbuhan. Bandung (ID): ITB Press.

Harborne JB. 1996. Metode Fitokimia: Penuntun Cara Modern Menganalisis Tumbuhan. Edisi kedua. ITB. Bandung.

Hidayat T, Nurjanah, Anwar E, Nurilmala M. 2018. Identifikasi dan karakterisasi rumput laut tropika (dari Kepulauan Seribu) sebagai sumber bahan baku kosmetik. CR Journal. 4(2): 49-62.

Hidayat T. Nurjanah, Anwar E, Nurilmala M. 2017. Pengembangan teknologi tepat guna (TTG) rumput laut tropika sebagai bahan baku kosmetik. CR Journal. 3 (1): 37-42.

Husni A, Deffy RP, Iwan YBL. 2014. Aktivitas antioksidan Padina sp. pada berbagai suhu dan lama pengeringan. Jurnal Pascapanen dan Bioteknologi Kelautan dan Perikanan. 9(2): 165-173.

Jeeva S, Marimuthu J, Domettila C, Anantham, Mahesh M. 2012. Preliminary phytochemical studies on some selected seaweeds from gulf of Mannar, India. Asian Pacific Journal of Tropical Biomedicine. S30-S33.

Juniarti, Delvi O, Yuhernita. 2009. Kandungan senyawa kimia, uji toksisitas (brine shrimp lethality test) dan antioksidan (1,1-diphenyl-2-pikrilhydrazyl) dari ekstrak daun saga (Abrus precatorius L.). Makara Sains. 13(1): 50-54.

Kar P, Laight D, Shaw KM, Cummings MH. 2006. Flavonoid rich grapeseed extracts: a new approach in high cardiovascular risk patients. International Journal of Clinical Practice. 60(11):1484-1492.

Kumar M, Vishal G, Puja K, Reddy C R, Jha B. 2011. Assessment of nutrient composition and antioxidant potential of Caulerpaceae seaweeds. Journal of Food Composition and Analysis. 24(2): 27-278.

$\mathrm{Lu}$ J, Lin PH, Yao Q, Chen C. 2010. Chemical and molecular mechanisms of antioxidants: Experimental approaches and model systems. Journal of Molecular Medicine. 14(4): 840-860.

Maharani F, Nurjanah, Suwandi R, Anwar E, Hidayat T. 2017. Kandungan bioaktif rumput laut Padina australis dan E.cotonii sebagai bahan baku krim tabir surya. Jurnal Pengolahan Hasil Perikanan Indonesia. 20(1):10-17.

Matanjun P, Mohamed S, Mustapha NM, Muhammad K. 2009. Nutrient content of tropical edible seaweeds, Eucheuma cottonii, Caulerpa lentillifera and Sargassum polycystum. Journal of Applied Phycology. 21(1): 1-6.

Manteu SH, Nurjanah dan Tati N. 2018. Karakteristik rumput laut cokelat (Sargassum policystum dan Padina minor) dari perairan pohuwato Provinsi Gorontalo. Jurnal Pengolahan Hasil Perikanan Indonesia. 21(3): 396-405.

Molyneux P. 2004. The use of the stable free radical diphenylpicrylhydrazyl (DPPH) for estimating antioxidant activity. Journal Science and Technology. 26(2): 211-219.

Nurjanah, Nurilmala M, Anwar E, Luthfiyana N, Hidayat, T. 2019. Utilization of seaweed porridge Sargassum sp. and Eucheuma cottonii as cosmetic in 
protecting skin. IOP Conference Series: Earth and Environmental Science. 278 (2019) 012055IOP.

Nurjanah, Nurilmala M, Anwar E, Luthfiyana $\mathrm{N}$, Hidayat, $\mathrm{T}$ 2017. Identification of bioactive compounds of seaweed Sargassum sp and E.cotonii as raw material suncreen cream. Proceedings of the Pakistan Academy of Sciences. 54(4): 311-318.

Nurjanah, Nurilmala $M$, Hidayat T, Fien Sudirjo. Characteristic seaweeds as raw material cosmetics. Aquatic Procedia. 7: 177-180

Parthiban C, Saranya C, Girija K, Hemalatha A, Suresh M, Anantharaman P. 2013. Biochemical composition of some selected seaweeds from tuticorin coast. pelagia. Research Library Advances in Applied Science Research. 4(3): 362-366.

Purba RD. 2001. Analisis komposisi alkaloid daun handeuleun (Graptophyllum pictum (Linn), Griff) yang dibudidayakan dengan taraf nitrogen yang berbeda. [Skripsi]. Bogor (ID): Institut Pertanian Bogor.

Renhoran M. 2012. Aktivitas antioksidan dan antimikroba ekstrak Sargassum polycystum. [Skripsi]. Bogor (ID): Institut Pertanian Bogor.

Rosyidah K, Nurmuhaimina SA, Komari N, Astuti MD. 2010. Aktivitas antibakteri fraksi saponin dari kulit batang tumbuhan kasturi (Mangifera casturi). Alchemy. 1(2): 53-103.

Salamah E, Eka A, Sri P. 2008. Penapisan awal komponen bioaktif dari kijing taiwan (Anadonta woodiana Lea). sebagai senyawa antioksidan. Buletin Teknologi Hasil Perikanan. 11(2): 119-133.

Septiana AT, Deddy M, Fransiska RZ. 2002. Aktivitas antioksidan ekstrak dikhlorometana dan air jahe (Zingiber officinale Roscoe) pada asam linoleat. Jurnal Teknologi dan Industri Pangan. 13(2): 105-110.

Sirait, M. 2007. Penuntun Fitokimia Dalam Farmasi. Bandung (ID): ITB Press.

Supriyanti W, Endang DW, Lia K. 2010. Uji aktivitas antioksidan dan penentuan kandungan antosianin total kulit buah manggis (Garcinia mangostana L). Majalah Obat Tradisional. 15(2): 64-70.

Vijay K, Balasundari S, Jeyashakila R, Velayathum Y, Masilan K, Reshma R. 2017. Proximate and mineral composition of brown seaweed from Gulf of Mannar International Journal of Fisheries and Aquatic Studies. 5(5): 106-112.

Yudiati E, Sedjati S, Sunarsih R, Agustian. 2011. Aktivitas antioksidan dan toksisitas ekstrak metanol dan pigmen kasar Spirulina sp. Jurnal Ilmu Kelautan. 16(4): 187-192.

Yanuarti R, Nurjanah, Effionora A, Hidayat T. 2017. Profil fenolik dan aktivitas antioksidan dari ekstrak rumput laut Turbinaria conoides dan Eucheuma cottonii. Jurnal Pengolahan Hasil Perikanan Indonesia. 20(2): 230-237.

Zhang Q, Junzen Z, Jingkai S, Angelica S, Dorothy A. 2006. A simple 96-well microplate method for estimation of total Polyphenol Content in Seaweeds. Journal of Applied Phycology. 18: 445-450. 